\title{
Banking Service Quality in the Middle Eastern and GCC Countries: Understanding the Future Research Directions
}

\author{
Akram Al-Jazzazi \\ Central Queensland University \\ Parves Sultan \\ Central Queensland University
}

\begin{abstract}
The aim of this paper is to review some of the key studies in banking service quality area with particular attentions to the Middle East and GCC (Gulf corporation council) countries and to explore some future research directions. This paper reviews the key literatures that were published in the last three decades in various academic journals. This review generated 12 research questions both for Islamic and conventional banking services operating in the Middle Eastern and GCC countries. This paper is a desk research and guides researchers with some possible research questions for empirical tests. This paper would be useful for the researchers and practitioners as a possible guide to design the research questions, and subsequently to test the research questions in the context of the banking service quality in the Middle Eastern and GCC countries.
\end{abstract}

Keywords: Service Quality, Middle East, Islamic Banking, Conventional Banking, Research Agenda, Literature Review.

\section{Introduction}

There exists two forms of banking systems which are currently used in operation by most of the Middle Eastern and Gulf Cooperation Council (GCC) states, and these are called conventional and Islamic banking systems. Conventional banks were formed before the Islamic banks and are directed by capitalist values of the Western world that lay emphasis on wealth as well as profit maximization (Olson and Zoubi, 2008). In the initial years of the Middle Eastern banking, majority of conventional banks were formed as branches of big international banks originating from the European countries. For example, the first commercial banking establishment in Saudi Arabia was established in the Port of Jeddah in 1927 and this was a division of the Netherlands trading society. Later, in the 1950s, the local commercial banks such as Riyadh Bank, National Commercial Bank were formed in Saudi Arabia (Yavas, 1988).

Islamic banking systems are always regarded as an option to conventional banking systems in the Middle East and GCC states. The past of Islamic banking can be linked 
back to early 1970s, the creation of the Nasser Social Bank in Egypt. Research found that there were an approximate of 35 Islamic banks in different countries distributed throughout the Middle East in 1985 (Erol and El-Bdour, 1989); and as at 2009, Islamic banks extended to over 50 countries (Hanif, 2010). It is approximated that the annual rate of growth of the Islamic banking industry was 8.2 percent during the 1990s. This growth spilled from the Middle East to other countries in Africa, Europe and Asia. Hence, the global Islamic banking industry developed at a rate of $30 \%$ between the years 2004 and 2008 (GatehouseBank, 2008; Khan and Bhatti, 2008). This growth made global conventional banks such as HSBC, Citibank, as well as Standard Chartered bank to provide Islamic banking services to its potential customers (Al-Smadi et al., 2013; Naser et al., 1999).

Despite the fact that Islamic and conventional banks offer services in the same market, their individual rates of growth, profitability and assets differ remarkably. This discrepancy is particularly massive in the Middle Eastern and GCC states. Although conventional banks naturally possess greater assets compared to Islamic banks, the growth rates of Islamic banks are much higher than that of the conventional banks. In this circumstance, Hanif (2010) approximated that the volume of Islamic banking had reached US\$951 billion and that the Islamic banks had been operational in over 50 states as at 2009.Similarly, Siraj and Sudarsanan (2012) established that the operating profit of Islamic banks had a more rapidly rate of growth compared to that of conventional banks. Further, according to Siraj and Sudarsanan (2012), Islamic banks have continuously reported a greater return on assets (ROA) than conventional banks. A further evaluation of customer total liability as well as deposits between the years 2006 and 2010 indicated a higher percentage of equity funds in Islamic banks (average 74 per cent) compared to conventional banks (average 55 per cent) (Siraj and Sudarsanan, 2012).

Contrasting conventional banks, Islamic banks generally seek out to boost societal equality as well as social and economic development for its customers or clients and stakeholders (Siraj and Sudarsanan, 2012). Islamic banks are structured and operated on the foundation of the principles of Islamic law (i.e., the Sharia) that prohibit the issuance or receipt of interest, and proposes that the bank and its clients to share profit and risks. The sharing of profit or loss with clients causes Islamic banks to face a greater risk compared to conventional banks (Abedifar et al., 2011). Hence, a trustworthy relationship is always carried out between these two parties involved (Askari et al., 2009).

The global development of Islamic banking has facilitated a considerable amount of research comparing the Islamic and conventional banking systems. The results of these studies are diverse in that some of these studies established no significant differences in these two systems of banking in terms of risk management practices (Hassan et al., 2009) and performance and profitability (Ansari and Rehman, 2011). However, other studies revealed significant differences in these two systems of banking in terms of profitability as well as leverage (Toumi et al., 2011), operational framework (Awan, 2009), and quality of assets, liquidity, and product or services offerings (Jaffar and Manarvi, 2011).

Having the largest crude oil reserve banks, GCC thus qualifies to become an oil based economy. The area has been ranked as the largest producer, manufacturer as well as 
exporter of petroleum and other related petroleum products (Erol and El-Bdour, 2009). During the period ranging 2000 - 2008, the economy of the GCC countries experienced a constant rapid growth. However, this rapid growth of the economy came to an abrupt stop in 2009. This was as a result of the coming up of international financial crisis in the late 2008. This economic boom later resumed its rapid growth rate in 2010 (Olson and Zoubi, 2011). Given the unpredictability in prices of oil, the GCC states realized that the only way to establish a sustainable growth in the economy which is long term is to embrace economic diversification. They began focusing their development on industries like tourism and financial services. As a result of this change, the banking industry in the GCC region geared up to embrace the change in an area that is experiencing a rapid acceleration in economic growth (Siraj and Sudarsanan, 2012).

Several studies have been carried out to establish the level of efficiency in the banking industry as well as their performance. The two main approaches employed in measuring efficiency in these banks include parametric and non-parametric methods (Askari et al., 2009). Non parametric methods do not put in to consideration the probability of measurement errors in the evaluation of the limit and could therefore overestimate the inefficiencies. On the other hand, the parametric method like the stochastic frontier approach applies distributional assumptions to facilitate disaggregation of the frontier in to a term that is inefficient and random, making the term arbitrary. (Olson and Zoubi, 2011).

This research aims at reviewing some of the main studies, published in the last three decades, on quality of banking service with particular interest to the Middle East and GCC countries, and delivers some future research instructions and directions. This paper is organized as indicated. The next section brings out service quality measures. We further discuss future research directions, and eventually, contribution then conclusion.

\section{Banking Service Quality Measures}

Several studies have developed service quality measures throughout cultures as well as types of financial or banking institutions. These measures are hinged on studies that include SERVQUAL (Parasuraman, Zeithaml, and Berry, 1985, 1988) as well as SERVPERF (Cronin and Taylor, 1992, 1994). Since the banking industry is distinctive in terms of its specific actors, operations, and standards, it demands the establishment of models which are specific to its characteristics and can precisely gauge service quality in the banking sphere (Zhou, 2004). In this connection, Zhou (2004), for instance, evaluated SERVQUAL measures using 316 samples of study from the United States of America (US). Results of this research showed that the four primary factors which contribute to banking service quality in the US include the willingness to correct errors, thoroughness and accuracy of service, consistency as well as reliability, and knowledge capability. Similarly, Karatepe et al. (2005) applied 20item survey instruments and realized that service environment, empathy, interaction quality, and reliability as the four main elements of service quality in the Northern Cyprus's banking industry. Guo et al.'s (2008) research applied 31-item survey instruments with 800 Chinese respondents and established the Chinese Banking Service Quality (CBSQ) framework. 
Avkiran's (1994) BANKSERV evaluation also followed the ideology of SERVQUAL and consisted 17 items and four dimensions such as staff conduct which relates to the bank's personnel service manner as well as presentation, credibility which relates to trust between the bank's staff and clients, communication which relates to verbal as well as written interactions between bank staff and clients, and customer accessibility that relates to the adequacy of staff to serve clients. In a later study, Avkiran (1999) conducted a research on the effect of three of these dimensions; communication, conduct of staff and customer accessibility to teller services on credibility and established that staff conduct is the main dimension of BANKSERV.

Aldlaigan and Buttle (2002) created the SYSTRA-SQ measure, which was made up of four dimensions of service quality that includes behavior quality, system quality, machine quality, as well as service transactional accuracy. System qualitytreats the service union as a system, and consists of attributes such as listening to clients, ease of availability as well as accessibility, speed of response, and organizational appearance; behavioral quality relates to howthe service was carried out by employees; machine quality relates to the reliability as well as performance of machines within an organization; and service transactional accuracy concerns clients perceptions transaction accuracy in terms of service as well as employee output.

Tsoukatos and Mastrojianni (2010) established a 27-item index in the perspective of the Greek retail banking sector which brings together SERVQUAL (Parasuraman et al., 1988) and Bank Service Quality (Bahia and Nantel, 2000). This index is known as the BANQUAL-R measure. The BANQUAL-R comprises of five dimensions: assurance, empathy, effectiveness, reliability, and confidence. The BANQUAL-R index brings in four of the five SERVQUAL dimensions which are assurance, reliability, empathy, and responsiveness as part of effectiveness as well as elements which are specific to the Bank Service Quality Model including, confidence and effectiveness.

Research indicates that the Islamic banking industry is established upon core differentiations such as the Islamic principles, priorities and values (Young, 2012). As a result, a several empirical studies established service quality measures for Islamic banking services (Al-Tamimi and Al-Amiri, 2003; Hossain and Leo, 2009; Othman and Owen, 2001). For example, the CARTER measure(Othman and Owen, 2001)was initially developed for the Kuwait Finance House, and provided a more clear differentiation between studies that employed SERVQUAL and SERVPERF (Abedniya et al., 2011; Haron and Azmi, 2008; Kumar et al., 2010; Taap et al., 2011). The CARTER model consists of 34 items and six dimensions which include compliance, meaning, adherence to the requirements of Sharia law, assurance implying, trustworthiness of employees and their communication, reliability which means the bank's ability to deliver superior performance according to imposed standards, tangibility that entails service facilities, including equipment, personnel, and communication material, empathy which includes individualized attention and focus on each client, and responsiveness which refer to willingness to respond to customer inquiries. Similarly, Abdullah et al.'s (2011) Bank Service Quality (BSQ) index model, in the context of Malaysia, was comprised of 29 items and three dimensions, which are, reliable communication, systemization, and responsiveness. A recent research conducted in the context of Iranian banking clients show that 
assurance and reliability are the most important dimensions of banking service quality in Iran (Ebrahimi and Moghadam, 2012).

Proportional studies between conventional and Islamic banking in the Middle Eastern and GCC countries used same approaches to appraise the nature and perceptions of consumers regarding banking service quality. Jabnoun and Khalifa's (2005) study, for instance, is based on SERVQUAL measure and put into consideration equal numbers of conventional as well as Islamic banks' clients in the United Arab Emirates (UAE); and realozed that gaps, for conventional banks lie on image reliability, personal skills dimensions, values; and for Islamic banks, these were found in the values and personal skills dimensions. Personnel or human skill dimension has also been laid emphasis upon in similar studies in the context of UAE banks (Jabnoun and AlTamimi, 2003).In the context of Saudi banks, Yavas (1988) established that a bank's reputation, convenience, experience, services offered, and personal relations were important predictors of a client's choice of bank. However, Jamal and Naser's (2002) study, with 200 banking clients of the Abu Dhabi Commercial Bank, realized that the relational and core dimensions of service quality affected customer satisfaction significantly, and that tangible dimension is negatively related to satisfaction. In contrast, Estiri et al.'s (2011) research established that empathy and communication were the most important determinants of Iranian banking clients' satisfaction.

Several studies came up with models based upon perceived service quality. For instance, Kassim and Souiden (2007) appraised the relationships among customer perception of service quality, image, and customer retention in UAE's retail banking sector, and realized that perceived quality is not a strong predictor of customer retention; instead, the study found that factors related to bank image are a strong predictor of customer retention. The current literature has also used customer satisfaction as a strong indicator of bank's success and found that fast service, availability of self-banking services and the degree to which bank staff are helpful and courteous are strong predictors of banking customers' satisfaction (Shin and Elliott, 2001; Al-Eisa and Alhemoud, 2009).

Aburoub et al. (2011)Investigated the link between the internal marketing practices of commercial banks in Jordan and customers' perceptions of service quality and satisfaction. They administered two sets of questionnaires that incorporated selected dimensions from SERVQUAL measure and included 384 customers and 231 employees of Jordanian commercial banks. The study found a positive correlation between a bank's internal marketing and service quality. Further evidence was found in Naser et al.'s (1999) study. In their study, Naser et al. (1999) used 206 samples to assess customer awareness and satisfaction towards Jordan Islamic Bank for Finance and Investment (JIBFI), and found that many were satisfied with the name of this bank, its image and reputation, and ability to maintain confidentiality. However, this study (Naser et al., 1999) found a great deal of dissatisfaction among the samples in regard to their banking services including the availability and education of some Islamic financial products such as how profit sharing(Murabaha)-equity participation (Musharaka)-and-any form of financial contract (Mudaraba) work. Although Erol and El-Bdour (1989) found that Jordanian banking customers do not differentiate the services offered by conventional and Islamic banks, Saleh (2006), in this context,suggested that Islamic banks operating in both Muslim and non-Muslim 
countries must educate and explain their clients about the Islamic banking terminologies and how that works.

Research also demonstrated that gender differences affect both perceived service quality expectations and service quality assessment (Raven and Welsh, 2004). In their study between Lebanese and Kuwaiti banking customers, Raven and Welsh (2004) revealed that men not only expect higher levels of service quality than women, but also they perceive higher levels of service quality particularly for assurance and reliability dimensions, and that Kuwaiti customers have lower perceptions of overall banking service quality than Lebanese customers. In terms of barriers of good perceptions of banking service quality, one study found that lack of employee empowerment, centralized management and lack of transformational leadership are some of the major barriers of forming good perceptions of service quality about banking services in Qatar (Chaker and Jabnoun, 2010).

Overall, the current research in the Middle Eastern banking service quality produces varied findings. These studies mainly found dimensions of perceived service quality and their culture specific importance, and barriers of good perceived service quality. In addition, some studies have developed culture specific models predicting satisfaction, perceived quality, and customer retention, while other studies have examined the demographic differences (e.g. gender) of perception of service quality in Middle Eastern banking services.

\section{Future Research in Banking Service Quality}

This paper has perilously reviewed the present service quality literature relevant to conventional as well as Islamic banks in the Middle East and GCC countries, where their culture consisting of language, religion, ethnic background, are relatively homogeneous, and identified a number of research questions in this research domain that require attention from researchers as well as practitioners alike. These are:

(1) How do demographic variables including income, gender, religion, age, and profession affect service quality perceptions?

(2) What are the customer's needs in terms of banking in the Middle East and GCC countries?

(3) What are the degree of differences between clients' expectations as well as the perceptions of banking services in the Middle East and GCC countries?

The majority of research in this sphere has primarily theorized SERVQUAL measure and examined client prospects and perceptions of service quality in Islamic and conventional banks in the Middle East and GCC states. In this perspective, our review finds the following research questions:

(4) What dimensions of service quality are truly unique to Islamic and conventional banking in the Middle Eastern and GCC countries,and how can other factors be identified through an analysis and modelling of industry performance? 
(5) What are the mainstay dimensions of perceived service quality thatare assorted between conventional and Islamic banking services among the banking clients across the Middle East and GCC countries?

(6) How do demographic variables such as religion, income, gender, professionand age, affectthe selection of banking servicesthat is either conventional or Islamic?

(7) Which of the service quality measures or a mix of measures such as SERVQUAL, SERVPERF, CARTER, BSQ, BANQUAL-R, SYSTRA-SQ, BANKSERV, and CBSQ is the most suitable for the Middle East and GCC countries?

Although a few research developed bank and culture specific service quality model and determined relationships between image, perceived service quality, satisfaction and customer retention (see, for example, Kassim and Souiden, 2007; Shin and Elliott, 2001; Al-Eisa and Alhemoud, 2009; Naser et al., 1999), it appears that these studies are missing several core constructs including Muslim customers confidence, trust and values and their relationships with banks' success in the Middle Eastern and GCC countries' banking services. Sultan and Wong's (2010a, 2010b, 2011, 2012, 2013) model, in this context may provide important insights for the researchers and practitioners. Therefore,

(8) What roles do consumers 'values, trust and confidence play in selecting a specific type of banking services in the Middle East and GCC region?

(9) Does perceived banking service quality predict banking success in the Middle Eastern and GCC countries?

There are a number of scarce areas of research including the banking service innovation, globalisation of the banking product or service and institutional/corporate branding. Islamic banking is relatively new, at least compared to conventional banking systems and practices, with an aim to serve the Muslims who believe in trade or business activities but not interest, in principle. Therefore, future research should explore the following research questions:

(10) What new banking service or product would be of value to the customers of the Middle Eastern and GCC countries?

(11) What constitutes or determines branding of Islamic banking services/products (including corporate branding)?

(12) How do varying tangible and intangible conditions influence customer satisfaction in Islamic and conventional banking in the Middle Eastern and GCC countries, and through what strategies can these influences be equalised?

\section{Contributions and Conclusion}

This evaluation on the existing development of quality service research in the banking sector of the Middle East as well as the GCC countries has highlighted some critical study questions for prospect research. It is anticipated that these questions, when answered using suitable and relevant research methodology, would offer valuable directions for the Middle Eastern and GCC countries' banking segment. To begin with, attention to the acknowledged research domains would offer practitioners in the banking sector invaluable an outlook on the banking profiles of clients in the Middle 
East and GCC countries. This will facilitate practitioners to strategically establish a plan on the best methods of meeting the banking desires of their clients. Additional research on the created domains would further indicate how demographic variables such as age, income, religion, gender, profession affect service quality perceptions as well as the choosing of banking services in either conventional or Islamic banks in the Middle Eastern and GCC states. Evidence-based results on these aspects would help bank practitioners in effectively and efficiently targeting potential clients as well as identifying service places which need improvements so as to sustain their clients and revenue stream.

Following a review of leading studies on service quality in the Middle East and GCC countries banking sector, research gaps relating to core homegenous and heterogenous dimensions of perceived service quality was established. This review further revelaled research gaps relating to core dimensions of perceived service quality that are heterogeneous between conventional and Islamic banking services among the banking customers across the Middle East and GCC countries. Furthermore, a gap on the extent of differences between consumers' expectations and perceptions of banking services was established. Future research studies that will attempt to bridge these research gaps will significantly aid both conventional and Islamic banks to determine which areas or dimensions of service quality they should focus on in order to meet consumers' expectations and enhance their competitive edge in the market.

Although a considerable number of research studies reviewed have employed the SERVQUAL model to measure service quality in Islamic and conventional banks in the Middle East and GCC countries, a mix of measures (e.g. SERVPERF, CARTER, BSQ, BANQUAL-R, SYSTRA-SQ, BANKSERV and CBSQ) have been used in other studies to investigate service quality. Consequently, there is no consensus on which overriding factors influence customer perception and customer satisfaction of service quality offered in Islamic and conventional banks. Therefore, there is need for future studies to establish which model is the most suitable for measuring service quality in the Middle East and GCC countries. This will lead to the establishment of more accurate finidings and provide clarity to banking service providers on consumers' expectations and perceptions of service quality.

Lastly, the reviewed studies have not effectively examined the relationship between the success of banking services in the Middle Eastern and GCC countries and core constructs such as customers confidence, values, trust, relationship with the bank and perceived service quality. Future studies that will examine these relationships will significantly help service providers to determine which areas of service quality they should focus on in order to enhance their profitability. In addition to this, future studies that will examine the factors that determine branding of services/ product in Islamic banks and new banking service/product that would be of value to customers of the Middle Eastern and GCC countries will not only aid service providers to effectively plan and execute suitable marketing strategies but will also help them to save costs and time associated with ineffective marketing plans.

Further, success in the delivery of banking services has caused a rapid economic growth in Middle Eastern and GCC member states. 


\section{References}

Abdullah, F., Suhaimi, R., Saban, G., \& Hamali, J. (2011). Bank Service Quality (BSQ) IndexAn indicator of service performance. International Journal of Quality \& Reliability Management, 28(5), 542.

Abedifar, P., Molyneux, P., \& Tarazi, A. (2011). Risk and Stability in Islamic Banking. Bangor: Bangor Business School, University of Wales.

Abedniya, A., Zaeim, M., \& Hakimi, B. (2011). Investigating the relationship between customers' perceived service quality and satisfaction: Islamic Bank in Malaysia. European J Soc Sci, 21(4), 603-624.

Aburoub, A. S., Hersh, A. M., \& Aladwan, K. (2011). Relationship between internal marketing and service quality with customers' satisfaction. International Journal of Marketing Studies, 3(2), p107.

Al-Ajmi, J., Hussain, H. A., \& Al-Saleh, N. (2009). Clients of conventional and Islamic banks in Bahrain: How they choose which bank to patronize. International Journal of Social Economics, 36(11), 1086-1112.

Al-Eisa, A. S., \& Alhemoud, A. M. (2009). Using a multiple-attribute approach for measuring customer satisfaction with retail banking services in Kuwait. International Journal of Bank Marketing, 27(4), 294-314.

Al-Smadi, A. A.-M., Hamdan, F., \& Almsafir, M. K. (2013). ISLAMIC BANKING VS CONVENTIONAL BANKING, DURING THE GLOBAL FINANCIAL CRISIS: MALAYSIA AS A CASE. Journal of Islamic and Human Advanced Research, 3(1).

Al-Tamimi, H. A. H., \& Al-Amiri, A. (2003). Analysing service quality in the UAE Islamic banks. Journal of Financial Services Marketing, 8(2), 119-132.

Al-Wugayan, A., Pleshko, L. P., \& Baqer, S. M. (2008). An investigation of the relationships among consumer satisfaction, loyalty, and market share in Kuwaiti loan services. Journal of Financial Services Marketing, 13(2), 95106.

Aldlaigan, A. H., \& Buttle, F. A. (2002). SYSTRA-SQ: a new measure of bank service quality. International Journal of Service Industry Management, 13(4), 362-381.

Amin, M., \& Isa, Z. (2008). An examination of the relationship between service quality perception and customer satisfaction: a SEM approach towards Malaysian Islamic banking. International Journal of Islamic and Middle Eastern Finance and Management, 1(3), 191-209.

Anderson, W. T., Cox, E. P., \& Fulcher, D. G. (1976). Bank selection decisions and market segmentation. The Journal of Marketing, 40(1), 40-45.

Ansari, S., \& Rehman, A. (2011). Financial performance of islamic and conventional banks in Pakistan: A comparative study. Paper presented at the 8th International Conference on Islamic Economics and Finance.

Askari, H., Iqbal, Z., \& Mirakhor, A. (2009). Globalization and islamic finance: convergence, prospects and challenges (Vol. 778): John Wiley \& Sons.

Avkiran, N. K. (1994). Developing an instrument to measure customer service quality in branch banking. International Journal of Bank Marketing, 12(6), 10-18. 
Avkiran, N. K. (1999). Quality customer service demands human contact. International Journal of Bank Marketing, 17(2), 61-74.

Awan, A. G. (2009). Comparison of Islamic and Conventional Banking in Pakistan. Proceeding of the 2nd CBRC, Lahore, November 14.

Bahia, K., \& Nantel, J. (2000). A reliable and valid measurement scale for the perceived service quality of banks. International Journal of Bank Marketing, 18(2), 84-91.

Benamraoui, A. (2008). Islamic banking: the case of Algeria. International Journal of Islamic and Middle Eastern Finance and Management, 1(2), 113-131.

Bloemer, J., De Ruyter, K., \& Peeters, P. (1998). Investigating drivers of bank loyalty: the complex relationship between image, service quality and satisfaction. International Journal of Bank Marketing, 16(7), 276-286.

Chaker, M. N., \& Jabnoun, N. (2010). Barriers to service quality in Islamic banks in Qatar. International Journal of Commerce and Management, 20(4), 296-307.

Cronin, J., Brady, M., \& Hult, G. (2000). Assessing the effect of quality, value, and customer satisfaction on consumer behavioral intentions in service environments. Journal of Retailing 76 (2), 193-218.

Cronin, J., \& Taylor, S. (1992). Measuring service quality: a re-examination and extension. Journal of Marketing, 56(3), 55-68.

Cronin, J., \& Taylor, S. (1994). SERVPERF versus SERVQUAL: reconciling performance-based and perceptions-minus-expectations measurement of service quality. Journal of Marketing, 58(1), 125-131.

Ebrahimi, M. R., \& Moghadam, A. H. (2012). A Survey to Recognize the Most Important Dimensions of the Service Quality of Iran's Commercial Banks. Journal of Management Research, 4(4), 131-142.

Erol, C., \& El-Bdour, R. (1989). Attitudes, behaviour, and patronage factors of bank customers towards Islamic banks. International Journal of Bank Marketing, 7(6), 31-37.

Erol, C., Kaynak, E., \& Radi, E.-B. (1990). Conventional and Islamic banks: patronage behaviour of Jordanian customers. International Journal of Bank Marketing, 8(4), 25-35.

Estiri, M., Hosseini, F., Yazdani, H., \& Nejad, H. J. (2011). Determinants of customer satisfaction in Islamic banking: evidence from Iran. International Journal of Islamic and Middle Eastern Finance and Management, 4(4), 295-307.

Evans, R.-1. (1979). Bank selection: it all depends on the situation. Journal of Bank Research, 12, 243-249.

Farrell, M. J. (1957). The measurement of productive efficiency. Journal of the Royal Statistical Society. Series A (General), 120(3), 253-290.

Galloway, L., \& Ho, S. (1996). A model of service quality for training. Training for Quality, 4(1), 20-26.

Gefen, D. (2002). Reflections on the dimensions of trust and trustworthiness among online consumers. ACM Sigmis Database, 33(3), 38-53.

Grönroos, C. (1984). A service quality model and its marketing implications. European Journal of marketing, 18(4), 36-44.

Guo, X., Duff, A., \& Hair, M. (2008). Service quality measurement in the Chinese corporate banking market. International Journal of Bank Marketing, 26(5), 305-327.

Hanif, M. (2010). Differences and Similarities in Islamic and Conventional Banking. International Journal of Business and Social Sciences, 2(2). 
Haron, S., \& Azmi, W. N. W. (2008). Determinants of Islamic and conventional deposits in the Malaysian banking system. Managerial Finance, 34(9), 618643.

Hassan, T., Mohamad, S., \& Bader, M. K. I. (2009). Efficiency of conventional versus Islamic banks: evidence from the Middle East. International Journal of Islamic and Middle Eastern Finance and Management, 2(1), 46-65.

Hegazy, I. A. (1995). AN EMPIRICAL COMPARATIVE STUDY BETWEEN ISLAMIC AND COMMERCIAL BANKS'SELECTION CRITERIA IN EGYPT. International Journal of Commerce and Management, 5(3), 46-61.

Hoffman, K. D., \& Bateson, J. E. (2002). Fundamentos de marketing de servicios: conceptos, estrategias y casos: Thomson.

Hossain, M., \& Leo, S. (2009). Customer perception on service quality in retail banking in Middle East: the case of Qatar. International Journal of Islamic and Middle Eastern Finance and Management, 2(4), 338-350.

Jabnoun, N., \& Al-Tamimi, H. A. H. (2003). Measuring perceived service quality at UAE commercial banks. International Journal of Quality \& Reliability Management, 20(4), 458-472.

Jabnoun, N., \& Khalifa, A. (2005). A customized measure of service quality in the UAE. Managing Service Quality, 15(4), 374-388.

Jaffar, M., \& Manarvi, I. (2011). Performance comparison of Islamic and Conventional banks in Pakistan. Global Journal of Management and Business Research, 11(1).

Jamal, A., \& Naser, K. (2002). Customer satisfaction and retail banking: an assessment of some of the key antecedents of customer satisfaction in retail banking. International Journal of Bank Marketing, 20(4), 146-160.

Kang, G.-D., James, J. . (2004). Service quality dimensions: an examination of Gronroos's service quality model. Managing Service Quality, 14(4), 266-277.

Karatepe, O. M., Yavas, U., \& Babakus, E. (2005). Measuring service quality of banks: scale development and validation. Journal of Retailing and Consumer Services, 12(5), 373-383.

Khan, M. M., \& Bhatti, M. I. (2008). Islamic banking and finance: on its way to globalization. Managerial Finance, 34(10), 708-725.

Kumar, M., Kee, F. T., \& Charles, V. (2010). Comparative evaluation of critical factors in delivering service quality of banks: an application of dominance analysis in modified SERVQUAL model. International Journal of Quality \& Reliability Management, 27(3), 351-377.

Lehtinen, U., \& Lehtinen, J. R. (1982). Service quality: a study of quality dimensions: Service Management Institute.

Levesque, T., \& McDougall, G. H. (1996). Determinants of customer satisfaction in retail banking. International Journal of Bank Marketing, 14(7), 12-20.

Metawa, S. A., \& Almossawi, M. (1998). Banking behavior of Islamic bank customers: perspectives and implications. International Journal of Bank Marketing, 16(7), 299-313.

Mohd Kassim, N., \& Souiden, N. (2007). Customer retention measurement in the UAE banking sector. Journal of Financial Services Marketing, 11(3), 217228.

Naser, K., Jamal, A., \& Al-Khatib, K. (1999). Islamic banking: a study of customer satisfaction and preferences in Jordan. International Journal of Bank Marketing, 17(3), 135-151. 
Olson, D., \& Zoubi, T. A. (2008). Using accounting ratios to distinguish between Islamic and conventional banks in the GCC region. The International Journal of Accounting, 43(1), 45-65.

Othman, A., \& Owen, L. (2001). Adopting and measuring customer service quality (SQ) in Islamic banks: a case study in Kuwait finance house. International Journal of Islamic Financial Services, 3(1), 1-26.

Parasuraman, A., Berry, L. L., \& Zeithaml, V. A. (1991). Perceived service quality as a customer-based performance measure: An empirical examination of organizational barriers using an extended service quality model. Human Resource Management, 30(3), 335-364.

Parasuraman, A., Zeithaml, V. A., \& Berry, L. L. (1985). A conceptual model of service quality and its implications for future research. The Journal of Marketing, 41-50.

Parasuraman, A., Zeithaml, V. A., \& Berry, L. L. (1988). SERVQUAL: A multipleitem sales for measuring customer perception of service quality. Journal of Retailing, 64(1), 12-40.

Raven, P., \& Welsh, D. H. (2004). An exploratory study of influences on retail service quality: a focus on Kuwait and Lebanon. Journal of Services Marketing, 18(3), 198-214.

Saleh, A. S., \& Zeitun, R. (2006). Islamic Banking Performance in the Middle East: A Case Study of Jordan. Faculty of Commerce-Economics Working Papers, 157.

Shin, D., \& Elliott, K. M. (2001). Measuring customers' overall satisfaction: a multiattributes assessment. Services Marketing Quarterly, 22(1), 3-19.

Siraj, K., \& Sudarsanan, P. (2012). Comparative study on performance of islamic banks and conventional banks in GCC region. J. Appl. Financ and Banking, 2(3), 123-161.

Sultan, P., \& Wong, H. Y. (2010a). Performance-based service quality model: an empirical study on Japanese universities. Quality Assurance in Education, 18(2), 126-143.

Sultan, P., \& Wong, H.Y. (2010b), "Service quality in higher education: a review and research agenda", International Journal of Quality and Service Sciences, Vol. 2, No. 2, pp. 259-272.

Sultan, P., \& Wong, H.Y. (2011), "Service quality in a higher education context: antecedents and dimensions", International Review of Business Research Papers, Vol. 7 No. 2, pp. 11-20.

Sultan, P., \& Wong, H.Y. (2012), "Service quality in a higher education context: an integrated model”, Asia Pacific Journal of Marketing and Logistics, Vol. 24 No. 5, pp. 755-784.

Sultan, P., \& Wong, H. Y. (2013). Antecedents and consequences of service quality in a higher education context: A qualitative research approach. Quality assurance in education, 21(1), 70-95.

Taap, M. A., Chong, S. C., Kumar, M., \& Fong, T. K. (2011). Measuring service quality of conventional and Islamic banks: a comparative analysis. International Journal of Quality \& Reliability Management, 28(8), 822-840.

Toumi, K., Viviani, J.-L., \& Belkacem, L. (2011). Actual Risk Sharing Measurement in Islamic Banks. Critical Studies on Corporate Responsibility, Governance and Sustainability, 2, 325-347.

Tsoukatos, E., \& Mastrojianni, E. (2010). Key determinants of service quality in retail banking. EuroMed Journal of Business, 5(1), 85-100. 
Yavas, U. (1988). Banking behaviour in an Arabian Gulf country: a consumer survey. International Journal of Bank Marketing, 6(5), 40-48.

Young, E. ( (2012)). the World Islamic Banking Competitiveness Report 2011-2012.

Zhou, L. (2004). A dimension-specific analysis of performance-only measurement of service quality and satisfaction in china's retail banking. The Journal of Services Marketing, 18(6\&7), 534-546. 